\title{
STRATIGRAPHY AND MATERIAL OF THE LOESS LAYERS AT MENDE, HUNGARY
}

\author{
Matti SeppäLä
}

SeppäLä, MAtri 1971: Stratigraphy and material of the loess layers at Mende, Hungary. Appendix by Kalevi Punakivi and Matti Seppälä. Bull. Geol. Soc. Finland 43, $109-123$.

Various experimental research methods were adopted in the present investigation for the analysis of the samples which were taken from 16 different places from the loess exposures in the brickyard at Mende, Hungary.

The quartz grains in the loess showed a fairly outworn stage of roundness.

The colour of the loess alternates from pale yellow to strong brown (2.5Y, 7.5YR).

The amounts of calcium and magnesium vary according to the stage of weathering. No constant proportion can be noticed between them. Magnesium is preserved proportionally better than calcium in the weathering. Carbonates mainly come from rock minerals.

The weight $\%$ of $\mathrm{Ca}$ in the carbonate concretion was 21.17 , that of $\mathrm{Mg}$ only 0.29 .

The phosphorus content in fresh loesses is a little larger than in soil horizons. The $\mathrm{pH}$ values in the aqueous suspension of the samples ranges from 8.3 to 8.75 .

Electric conductivity values are also high - between 64.1 and $118.7 \mathrm{~S}$.

The C-14 dating was done with material from the third paleosol horizon counting downwards from the surface. The computations yielded a radiocarbon age of $27200 \begin{aligned} & +1400 \\ & -1\end{aligned} 100$ yr. B. P., which corresponds to the Paudorf Interstadial between Würm stages II and III.

At the end of the paper, the results obtained are compared with opinions generally held as to the origin of loesses. The present author is in favour of the diagenetic theory of loess origin.

Matti Seppälä, Department of Geograpby, University of Turku, Turku 2, Finland.

Kalevi Punakivi, Geological Survey of Finland, Otaniemi, Finland.

\section{CONTENTS}

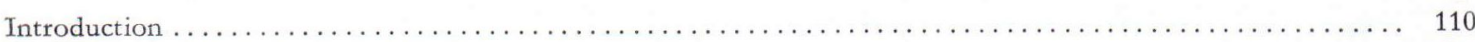

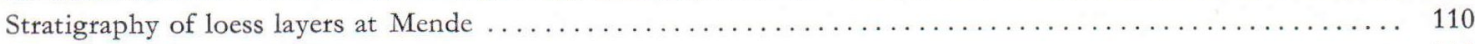

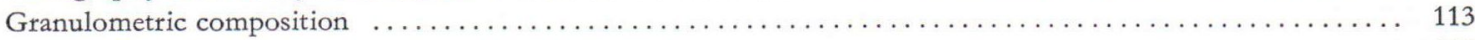

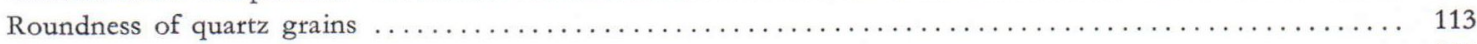

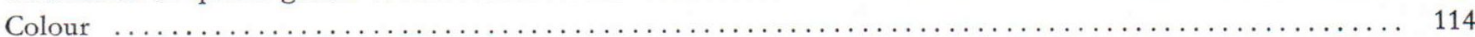


Page

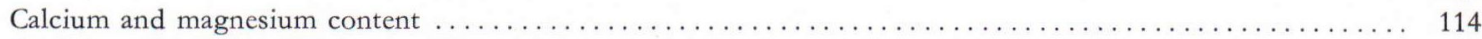

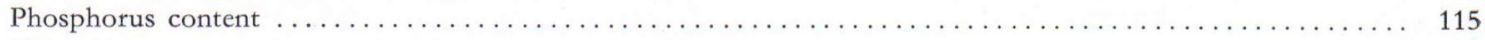

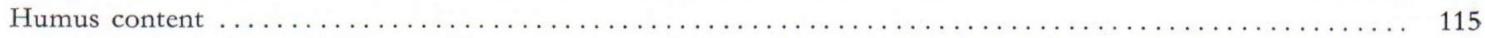

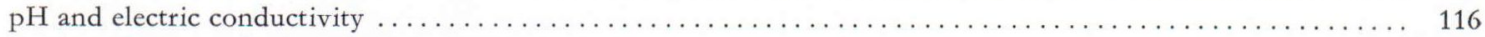

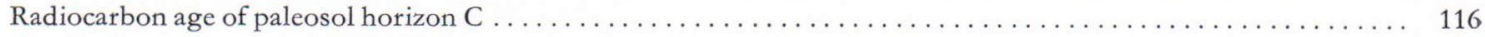

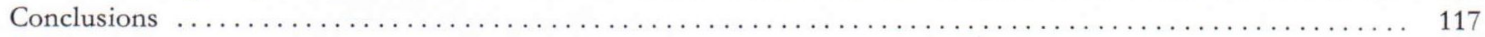

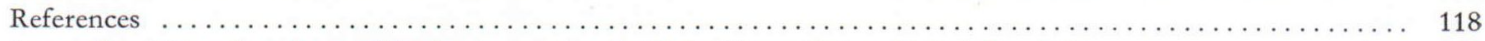

Appendix: Mineral analyses of the loess samples (by Kalevi Punakivi and Matti Seppälä) . . . . . . . . . . . 119

\section{Introduction}

Hungary, in the middle of the Carpathian Basin, serves as a large sedimentation basin to which weathering-detached loose ingredients from the surrounding mountains have continuously sedimentated since the sub-tropic Middle Pliocene Era (Fink 1964 p. 451). This accounts for the formation of sediment deposits even as thick as 3000-4000 metres (Rónai 1965). The surface of the major part of Hungary is covered by loess, which is more than 50 metres thick in some places (Ádám, Marosi \& Szilárd 1954).

Palaeogeographically, the stratigraphy of loesses is a very important object of investigation, which concerns conditions during the Pleistocene Era. A loess exposure of only 10 metres often reveals $3-5$ buried fossil soil horizons indicating certain stages in the development of the climate. Owing to local erosion

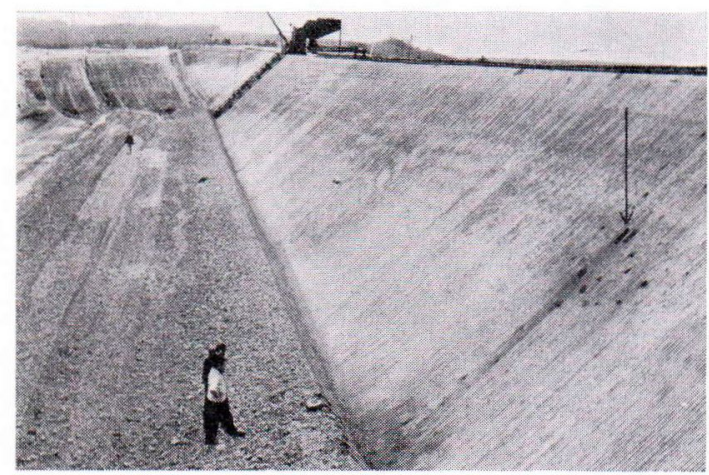

Fig. 1. Part of the loess exposure at Mende. The arrow points to the place from where sample 7C (I3130) was taken. Photographed by the author. April 14, 1967. and accumulation during loess formation, it is not easy, however, to connect the fossil soil horizons from different places with each other. Investigations based on both pedological, archeological, palaeontological, and radiocarbon datings have all facilitated the palaeogeographical interpretation of the phenomena observed in loess layers (e.g. Haase 1963).

The samples analysed in the laboratory were collected by the author from the pit of a brickyard in the valley of the River Tápio at Mende, $40 \mathrm{~km}$ NE of Budapest $\left(47^{\circ} 25^{\prime} \mathrm{N}\right.$ Lat, $19^{\circ} 25^{\prime}$ E Long). The characteristic features of the area include many-branched derasion valleys which have been eroded into the loess with ridges between them (Pécsi 1965a p. 332-333) which are about 220 m.a.s.l. Hungarians have investigated the same profiles very intensively. However, the research methods adopted in the present investigation have yielded some new and supplementary data on loess layers. An attempt has been made to apply the observations to opinions generally held as to the origin, age, and ways of formation of loesses.

\section{Stratigraphy of loess layers at Mende}

The stratigraphy of the loess layers at Mende has been elucidated thoroughly by several previous articles (e.g. Pécsi 1965a, 1965b, 1966, Stefanovits 1965, Pécsi \& Hahn 1969). Based on these, some general points concerning stratigraphy are repeated here (see Fig. 2).

On the surface there is the present chernozem soil. Sample 1 was taken from the sandy slope loess beneath it. 


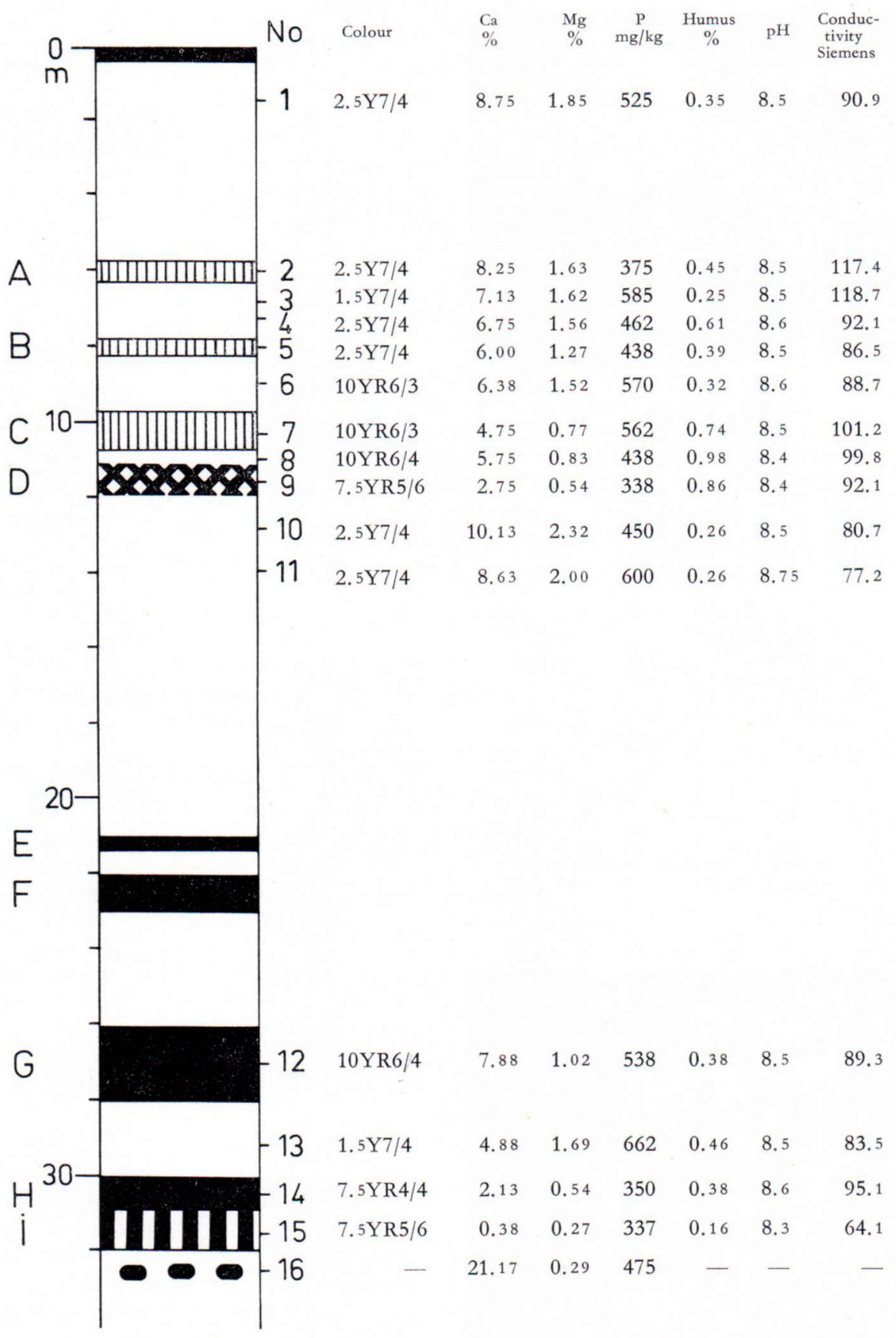

Fig. 2. An cutline of the loess layers at Mende according to Pécsi 1966 (Tafel 33). A-C weakly developed paleosols, D a chernozem-type soil, E-H chernozem, I brown forest soil. The numbers of the samples show the places from where they were taken. Sample 16 is from a carbonate concretion (see Fig. 3). 


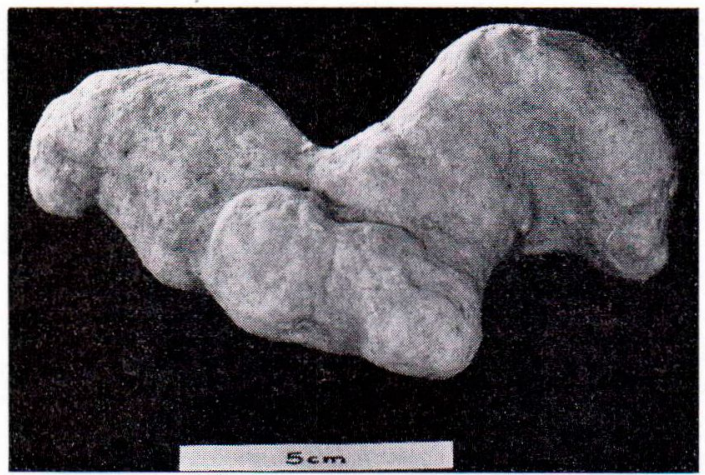

Fig. 3. Small carbonate concretion (»loessdoll»), sample 16 in Fig. 2. Photographed by Martti Valtonen.

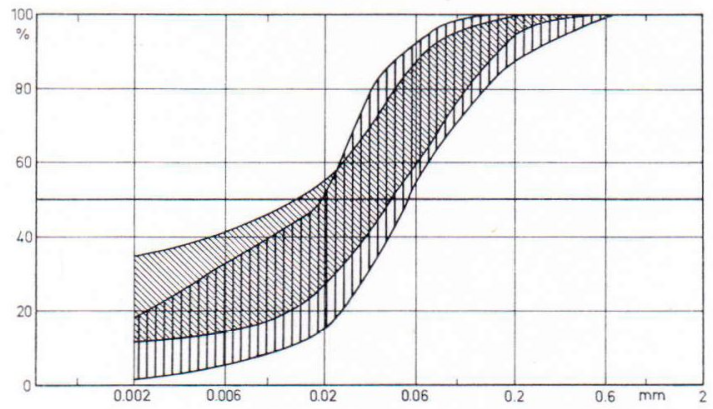

Fig. 4. The grain sizes in the loess layers at Mende as a cumulative graph. Constructed on the basis of the analyses made by Pécsi (1965 a) and Stefanovits (1965). The part with vertical lines shows the grain size curves of fresh loesses. Skew lines show the area of the grain size curves of soil horizons.

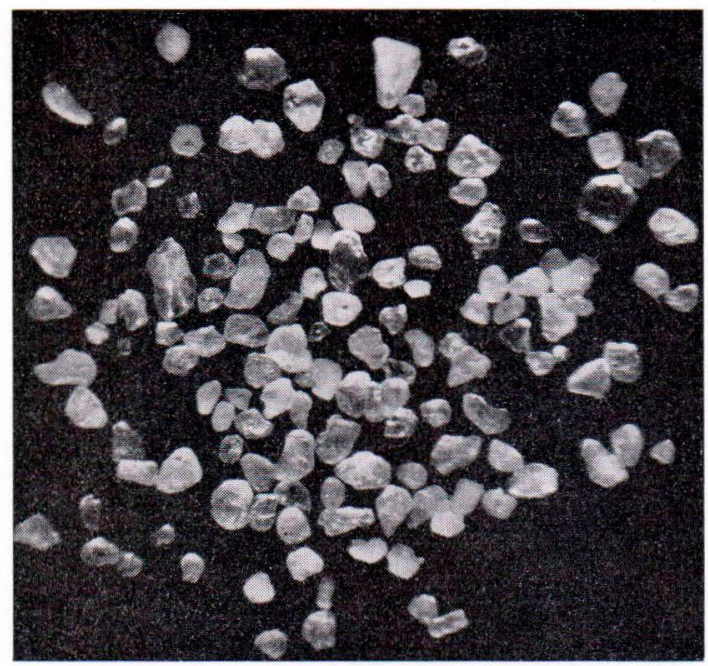

Fig. 5. Quartz grains from sample 7. Fraction 0.074 $0.125 \mathrm{~mm}$. Photographed by the author.
The youngest fossil soil (A), is at a depth of approximately 6 metres. It is a weakly developed humus carbonate layer (sample 2).

The fresh material beneath this is defined by Pécsi (1965 a p. 335) as slope loess containing alittle sand (samples 3 and 4).

Soil horizon B (sample 5) is also a weakly developed humus carbonate layer.

In the loess layer (sample 6) between soils B and C, which is about 1.5 metres thick, there are very many shells of snails and bones of mammoths (Elephas primigenius).

Fossil soil horizon $\mathrm{C}$ at a depth of about 10 metres is meadow soil about 1.5 metres thick and containing charcoal and bones of mammoths. Samples 7 and $7 \mathrm{C}$ were taken from this horizon; the latter was dug out of a fire pit in which the loess had partly burned and turned to brick-red. A radiocarbon dating of sample $7 \mathrm{C}$ was made. Sample 7 represents the soil horizon proper.

The material in the following intermediary layer (sample 8) is sandy loess with a fairly large humus content. Rodents and other animals digging holes in the soil have mixed the original stratigraphy by digging soil-filled burrows (crotowinas).

Fossil soil D (sample 9) is a dark brown, roughly 1 metre thick horizon resembling chernozem, and also with crotowinas.

Crotowinas have also mixed the fresh loess beneath horizon D to some extent. Samples 10 and 11 were taken from the upper part of the horizon.

$\mathrm{E}$ and $\mathrm{F}$ fossil soils are chernozem. The author was not able to collect any samples from the depth between 15-26 metres because there were no fresh exposures in spring 1967.

$\mathrm{G}$ and $\mathrm{H}$ soils are also chernozem. In the loess between them (sample 13) it is possible to notice a slightly laminated structure.

Fossil soil I (sample 15) is a brown forest soil horizon. It forms together with the chernozem $(\mathrm{H})$ above it a two metre thick soil complex from which plenty of calcium has leached. The lime accumulation has formed potato-like carbonate concretions beneath the soil complex. Calcium, magnesium, and phosphorus analyses were made using the concretion in Fig. 3 (sample 16).

The loess still continues on down at least 10 metres deeper, but the exposures in the spring of 1967 were from no deeper than 33 metres.

The weathered layers in the loess mainly represent the illuvial zones of the soils. Mende is a rewarding object of investigation because all the main soil horizons typical of Hungary since 
the Riss-Würm Interglacial occur there (Pécsi 1965b, 1968).

There is almost no laminated structure in the loesses at Mende, but material is mainly a relatively unstratified, homogeneous and porous mass.

\section{Granulometric composition}

Pécsi (1965a, 1966) has made several analyses of the grain size of the fresh loess layers at Mende. Stefanovits (1965) has investigated the grain sizes in the soil horizons of exposures. The present author has enumerated these data by circumscribing, in a half-logarithmic scale, the areas in which the grain size curves fall (Fig. 4). The medians of the cumulative curves are almost invariably in the grain size area of $0.01-0.05$ $\mathrm{mm}$, which is, indeed, the most typical for loesses.

The effect of weathering is clearly shown by the abundance of clay fractions $(<0.002 \mathrm{~mm})$ in the samples taken from soil horizons. The finest fractions, usually exceeding $25 \%$, are dominant in soil horizons representing the chernozem type. The proportion of the clay fraction in a forest soil ( $\mathrm{I}$ in Fig. 2) even exceeds $30 \%$ (Stefanovits 1965 p. 340).

The proportion of the clay fraction in fresh loesses is less than $10 \%$ in general (Pécsi 1965a p. 336). The coarsest loesses containing sand are situated in the surface part of the layer. Loesses seldom have grains larger than $0.6 \mathrm{~mm}$ in diameter.

\section{Roundness of quartz grains}

Part of sample 7 was washed in $10 \%$ hydrochlorid acid, rinsed with distillated water, wetsifted and dried. The quartz grains in the fraction of $0.074-0.125 \mathrm{~mm}$ were separated for photographing with a binocular microscope. In the enlargement of the photograph (Fig. 5), the percentages of the plain $(\mathrm{P})$, concave $(\mathrm{C})$, and convex (V) faces in the silhouettes of 100 grains were measured according to the Szadeczky-
Kardóss method (Köster 1964 p. 180-181). The percentual proportions of the faces are to be seen in the triangular diagram (Fig. 6) showing the differences in the roundness of the grains. Most quartz grains are slightly rounded, but there are few very well rounded. The roundness index of sample 7, computed according to Szadeczky-Kardóss, was $\mathrm{V}+\frac{\mathrm{P}}{2}=5.9$, i.e. the material is fairly rounded. The index value of completely rounded material is 10 (Pécsi \& Pécsiné 1959).

300 quartz grains from the same sample were examined with the binocular microscope according to the Russell-Taylor method (Köster 1964 p. 183 - 185). The roundness value obtained was $2.31(\max 5)$.

These results agree with Charlesworth's (1966 p. 513) general observation that the grains of loesses are sometimes round and subangular but usually sharp and uneffected by weathering.

$60 \%$ of the grains had a mat surface probably caused by aeolian activity. Though sample 7 was taken from the illuvial zone of a fossil soil, not all of the grains are mat-faced. This would indicate that chemical weathering is not a partic-

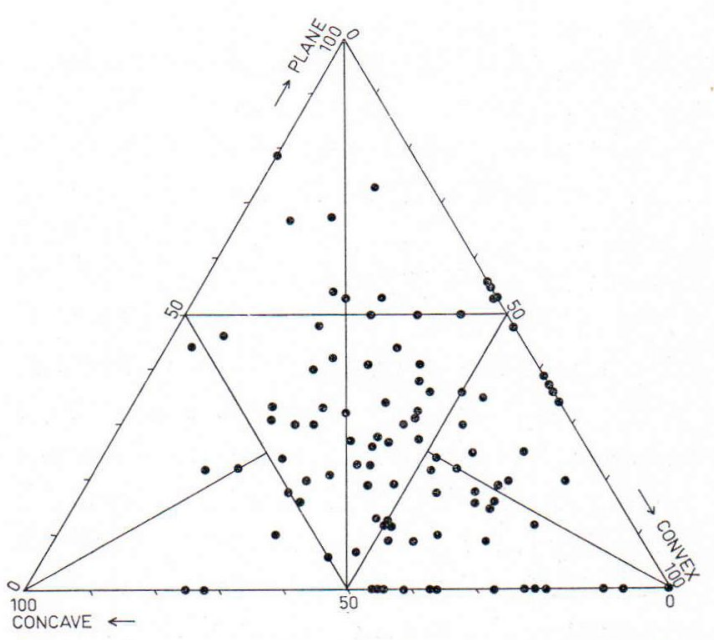

Fig. 6. Triangular graph showing the roundness of a hundred quartz grains from sample 7 (Fig. 5), according to the Szadeczky-Kardóss method. 
ularly important factor in the frosting of grains.

It is hardly possible that the material would have worn significantly during the accumulation of loesses, for such fine material moves suspended both in water and in air. It cannot be inferred from the roundness and surface texture of the material whether it was worn during loess accumulation or due to earlier processes. The great dispersion of roundness refers to grains of various kinds of origin. In that case earlier aeolian and fluvial sediments as well as chemical and mechanical weathering products must be considered.

\section{Colour}

Limonite and humus are usually mentioned as the agents which cause the characteristic colour of loess (e.g. Berg 1964 p. 45). The colours of the samples taken from Mende were identified by comparing them when air-dried with the Munsell Soil Color Charts.

The colours of the soil horizons fell into groups 2.5Y, 10YR and 7.5YR (pale yellow, yellowish or pale brown, and strong brown). Fink (1964 p. 453), for example, has observed that the two latter colours are typical of the B horizon of fossil soils in Austria.

Pale yellow is a common colour of fresh loess at Mende. In the youngest layers, there are no big differences in colour between fossil soil horizons (A-C) and fresh loess (Fig. 2). Colour $1.5 \mathrm{Y} 7 / 4$ in samples 3 and 13 means one between colours $10 \mathrm{YR} 7 / 4$ and $2.5 \mathrm{Y} 7 / 4$, which is alittle browner than pale yellow.

It is evident that the soiling process had been going on at the same time as loess had been accumulating among the vegetation. Thick and dark fossil soil horizons are evidence of long intervals in loess accumulation. The weathering of loess layers alone was hardly responsible for the yellowish colour of the loess. It is most probable that the depositing material was already yellowish owing to earlier weathering. Consequently it is impossible to distin- guish between the influence of local circumstances and factors that have previously affected the colour.

\section{Calcium and magnesium content}

Guenther (1961 p. 11) divides the chalk in loesses into primary and secondary types of occurrence. Primary or syngenetic chalk includes: 1) calcium carbonate grains, which only occur in weakly weathered loesses and 2) organic chalk, which mainly originates from shells of snails which had become buried in the loess. Secondary or epigenetic chalk comprises: 1) the calcium carbonate film covering other mineral grains, 2) the chalk filling the hollows of roots and other places both above and beneath the soils. 3) carbonate concretions or loess dolls which are big lumps beneath soil horizons, and 4) white loess layers accumulated from the ground water containing calcium.

The chalk at Mende occurs in all the other forms except for the latter coherent lime layer. Thus the calcium in loesses is not evenly distributed in the material, but migrates in the loess layers with the ground water and the water filtering down through the layers. The heterogeneousness of the material was taken into consideration by making the analysed loess samples as homogeneous as possible before the material needed for the analyses was separated.

For the $\mathrm{Ca}$ and $\mathrm{Mg}$ analyses, the 1-gramme samples were boiled in a weak hydrochlorid acid solution to dissolve the carbonates. The analysis was carried out with a Perkin-Elmer 290 AAS (Atomic Absorption Spectrophotometer). The calcium and magnesium contents are given in weight percentages (Fig. 2). The corresponding $\mathrm{CaCO}_{3}$ and $\mathrm{MgCO}_{3}$ content values were obtained by multiplying the $\mathrm{Ca}$ values by 2.5 and the $\mathrm{Mg}$ values by 3.06. Thus the values of the $\mathrm{CaCO}_{3}$ content in samples $1-15$ vary from $0.95-25.32$ weight $\%$, and those of the $\mathrm{MgCO}_{3}$ content from $0.83-7.10$ weight $\%$. When determining these values it was supposed that all the calcium and magnesium come from carbonates.

Guenther (1961 p. 12) states that the ratio of 
$\mathrm{CaCO}_{3}: \mathrm{MgCO}_{3}$ in loesses is $6: 1$. On the basis of the observations in the present paper it can be concluded that $\mathrm{Mg}$ dissolves relatively less readily than $\mathrm{Ca}$ during weathering processes. Thus the proportion of calcium to magnesium alternates in the loesses at Mende, and no ratio of general application can be found ( $c f$. Fig. 7).

The values of the $\mathrm{Ca}$ and $\mathrm{Mg}$ content are lower in soil horizons than in fresh loesses. The scarcity of $\mathrm{Ca}$ and $\mathrm{Mg}$ in soils $\mathrm{H}$ and $\mathrm{I}$ is due to a long phase of humid climate and to the strong eluviation caused by it. This also resulted in the formation of the carbonate concretion zone beneath. The calcium content of the concretion (Fig. 3) is 21.17 weight $\%$, while the magnesium content is only 0.29 weight $\%$ (Fig. 2).

The analysis of snail shells (Pedicella sp.) collected from the surface of the earth at Mende gave $39.89 \%\left(=99.7 \% \mathrm{CaCO}_{3}\right)$ and $0.07 \%$ magnesium $\left(=0.2 \% \mathrm{MgCO}_{3}\right)$. It can be inferred from this that all the carbonates in loesses cannot possibly be of organic origin, but that they probably mainly originate from dolomite and dolomitic limestone (see Appendix). The mineragenic origin of calcium and magnesium is also indicated by the fact that well-preserved, unweathered snailshells are regularly found in loesslayers.

\section{Phosphorus content}

The phosphorus contents of the samples were examined in the laboratory of Viljavuuspalvelu Oy, Helsinki, by photoelectric colorimeter. The method has been published in the series Kungl. Landbrukstyrelsens Kungörelser M. M. 1965 No. 1 p. $14-15$. It uses as a reagent $2.00 \mathrm{M}$ $\mathrm{HCl}$ in which $2 \mathrm{~g}$ of the sample is boiled for 2 hours in a double boiler. $5 \mathrm{ml}$ of the extract is taken and mixed with $35 \mathrm{ml}$ of distilled water. The measurement is performed with the diluted solution.

On the basis of the results (Fig. 2), it can be concluded that phosphorus compounds eluviate to some extent in connection with weathering. The total phosphorus contents in fossil soils alternated between $338-562 \mathrm{mg} / \mathrm{sample} \mathrm{kg}$ (=ppm), and in fresh loesses between 438-662 $\mathrm{mg} / \mathrm{sample} \mathrm{kg}$. The concretion (sample 16) contained $475 \mathrm{mg} / \mathrm{kg}$ phosphorus.

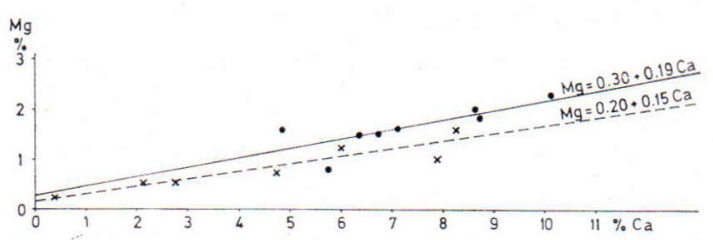

Fig. 7. The linear correlations of the calcium and magnesium contents in samples $1-15$. The figures are weight percentages from the whole sample. Points indicate fresh layers $(\mathrm{Mg}=0.30+0.19 \mathrm{Ca}, \mathrm{r}=0.76)$ and crosses fossil soil samples $(\mathrm{Mg}=0.20+0.15 \mathrm{Ca}$, $r=0.92$ ) (see also Fig. 2). $r=$ Bravais-Pearson coefficient of linear correlation.

The value of $750 \mathrm{mg} / \mathrm{sample} \mathrm{kg}$ in sample $7 \mathrm{C}$ is a significant exception to the general phosphorus content values. The abundance of phosphorus may indicate that the sample is probably from a man-made fire pit, for a clear increase of the phosphorus content in the soil has been noticed even in the temporary dwelling places of man (Lorch 1940 p. 633).

\section{Humus content}

The humus content was determined from $5 \mathrm{~g}$ samples by titration. The reagent consisted of $40 \mathrm{ml}$ concentrated sulphuric acid $\left(\mathrm{H}_{2} \mathrm{SO}_{4}\right)$ and $25 \mathrm{ml} 2 \mathrm{~N}$ potassium bicromate $\left(\mathrm{K}_{2} \mathrm{Gr}_{2} \mathrm{O}_{7}\right)$. The solution was boiled in a double boiler for 2 hours. The volumetric flask was filled up to $250 \mathrm{ml}$ with distilled water. $25 \mathrm{ml}$ of the solution was taken for titration and diluted with distilled water up to $200 \mathrm{ml}$. The unused bicromate was reduced with $5 \mathrm{ml}$ $20 \% \mathrm{KJ}$. The iodine liberated was titrated with $0.1 \mathrm{~N}$ sodium tiosulphate solution $\left(\mathrm{N}_{2} \mathrm{~S}_{2} \mathrm{O}_{3} \cdot 5 \mathrm{H}_{2} \mathrm{O}\right)$. In addition to the actual analyses, a »blind test» was made without any soil sample. The amount of sodium tiosulphate used for this test was compared with that needed for the analyses respectively. The amount of oxygen used in the analysis reactions can be calculated by subtraction. The humus content is computed by using the formula:

$$
\mathrm{Hu}=\frac{0.518 \cdot(\mathrm{B}-\mathrm{b})}{\mathrm{a}} \%
$$

in which $\mathrm{Hu}=$ amount of humus in percentages, $\mathrm{B}=$ amount of sodium tiosulphate in $\mathrm{ml}$ used in the blind test, $\mathrm{b}=$ amount of $\mathrm{Na}_{2} \mathrm{~S}_{2} \mathrm{O}_{3}$ solution in $\mathrm{ml}$ used in the titrating of the sample, $\mathrm{a}=$ amount of the soil sample in grams. The method is an application of the Rauterberg \& Kremkus method (Thun 1955 p. 48-49) made by Pentti Alalammi. 
The humus content in samples $1-15$ did not exceed $1 \%$. Stefanovits (1965 p. 340) got the same result when investigating the fossil soils at Mende. The humus contents of soil horizons $G$, $\mathrm{H}$ and $\mathrm{I}$ in the present paper (Fig. 2) are the only ones that diverge significantly from the values $0.33-0.78 \%$ given by Stefanovits. The humus content in sample 8 is markedly high $(0.98 \%)$ in comparison with the humus content values in the soil horizons. As also revealed by the colour index, it is very difficult to distinguish this horizon from paleosols $\mathrm{C}$ and $\mathrm{D}$. The humus content of sample $7 \mathrm{C}$ was 2.74 weight $\%$.

As soiling proceeds and the humus content increases so calcium and magnesium are leaching. They are usually only to be found in small amounts in humus-rich layers (Pécsi 1965a Abb. 16).

The relatively high values of the humus content $(0.25-0.98 \%)$ in fresh loesses seem to indicate that soiling was continually taking place during the loess accumulation. On the other hand, the reason may be that humus was driven to the area during the accumulation phase ( $c f$. the chapter on colour). The activity of plants' roots and animals are also factors affecting the mixing of humus. The amount of humus in the soils $(0.16-0.86 \%)$ is small in comparison with the present soil horizons. Kubiëna (1953 p. 242) points out that the humus content of e.g. chernozem is $4-16 \%$.

\section{$\mathrm{pH}$ and electric conductivity}

To investigate the $\mathrm{pH}$ of the loess samples, 5 grams of air-dried material was silted into $100 \mathrm{ml}$ distilled water and left for 24 hours. The sample was mixed and the measurement of the acidity of the solution was carried out by means of a pH measure model E350B Metrohm Herisau.

The results (Fig. 2) show that loesses are very alkaline. The $\mathrm{pH}$ varies in soil horizons from 8.3 to 8.6 and in fresh loesses from 8.5 to 8.75 , the reason being the great number of alkaline cations.

Resistance measurements were made with the same water solution using a battery gadget
(Norma RW1) to determine the electric conductivity and the extent to which the salt content varies. According to the measurements, loesses contain abundant electrolytes. The electric conductivity in samples $1-15$ ranged from 64.1 to 118.7 Siemens $\left(1 \quad \mathrm{~S}=1 \Omega^{-1}\right)$. The conductivity values were approximately as great in soils as in fresh loesses. Only sample 15 had a value which was considerably smaller than the others, $64.1 \mathrm{~S}$, while that of sample $7 \mathrm{C}$ was $140.8 \mathrm{~S}$

Conductivity generally increases with increasing humus content, although correlation is not clear.

\section{Radiocarbon age of paleosol horizon C}

Pécsi (1965b, 1966, 1968) has given a general chronological scheme as to the age relationships of the fossil soils of loesses in Hungary. According to him, the double soils $\mathrm{H}$ and I (Fig. 2) date from the Riss-Würm Interglacial, which is considered to have ended 75000 years ago (e.g. Büdel 1960). The other soils at Mende are younger. Quoting Pécsi further, the Würm glaciation divides into three glacial periods between which there are two interstadial phases. Several soil horizons were formed during these phases.

A radiocarbon dating (Lab.no. I-3130) of sample 7C was made in the Isotopes, Inc., Westwood laboratories (USA). The sample was taken from a buried fire pit approximately in the centre of soil horizon C. Sample I-3130 consisted of soil, small charcoal fragments and other organic material. According to the statement of the laboratory, various components could not be separated, and so the sample was treated and combusted in bulk. The radiocarbon age obtained was

$$
27200 \begin{array}{r}
+1400 \\
-1100
\end{array} \text { years B.P. }
$$

This dating was also reported in the bulletin, Radiocarbon 1969 (p. 81). It confirms an earlier dating of the same horizon by Pécsi (1966 p. 245), for the difference is not very significant: 
$29800 \pm 600$ yrs. B.P. (Lab.no. MO-422).

The paleosol horizon $\mathrm{C}$ in question was formed at the end of Middle Würm during the so-called Paudorf Interstadial, which was between 35000 and 25000 years B.P. according to different scientists (e.g. Haase 1963, Frenzel 1964 p. 2627). It has been stated that soil formation also took place in other loess areas at that time. Gross (1962-63 p. 62-63, 65) regards the period between 27000 and 25000 as the proper Paudorf Interstadial, which would have been preceded by the second deglaciation phase of the Würm glaciation starting 31000 yrs. B.P.

For comparison, some other datings of paleosols may be mentioned:

In Austria, Stillfried: $27900 \pm 300$ (Gro-2523) and $28120 \pm 200$ (Gro-2533), and Unterwisternitz: $28100 \pm$ 300 and $29900 \pm 300$ (Fink 1962 p. 14, 16). In Iowa, USA, the ages of paleosols vary between $16500 \pm 500$ (I-1419) and $29000 \pm 3500$ (I-1269) (Ruhe 1968 p. 59). In Zelzate, Belgium, fossil soil was dated as $28200 \pm 270$ (GrN-4783) (Paepe 1969 p. 47-49). In Sittard, Holland, the figures were $27900 \pm 670$ (Kuyl \& Bisschops 1969 p. 101). From Czechoslovakia, a dating in Věstonice is: $28300 \pm 300$ (GrN-2092) (Kukla \& Lozek 1969 p. 54). The so-called soil of Briansk in the U. S. S. R. is close to the age of paleosol $\mathrm{C}$ at Mende. This was dated as $24920 \pm 1800$. Two soils from Molotova are also rather close: $23000 \pm 800 \quad(23700 \pm 320)$ and $28100 \pm 1000$ (29 650土1 320) (Ivanova 1969 p. 152, 155).

\section{Conclusions}

The stage of weathering is of decisive importance in the characteristics of loess layers. There are more clay fractions in soil horizons than in fresh loesses. The colour of the loess varies depending on the stage of weathering. Carbonates and phosphorus compounds are dissolved in weathering processes and precipitated into other layers. The $\mathrm{pH}$ values of soil horizons are slightly smaller than those of fresh loesses. However, weathering has not had any significant influence on humus content and electric conductivity. The accumulation of loess has been so slow that weathering has had some influence on all loess. However, the eluvial soil hypothesis of the origin of loesses by Berg (1964) does not hold good as such, for weathered paleosols of various phases occur in loess exposures. They cannot be explained without consecutive events of accumulation. Loess cannot, however, be regarded as a mere product of weathering because the roundness of its quartz grains is very heterogeneous. Thus the material of loess obviously originates from several different sources. "Chief source of loess was outwash in the valley of the Danube, derived from glaciers in the Alps and in the Carpathians» (Flint 1967 p. 191). This is a very simplified picture, for loesses are derived from varied sources. Fluvial and aeolian processes and solifluction are mentioned as depositing factors (Kádár 1960, Pécsi 1965b, 1968, Rónai 1965). The Tertiary weathered layers in the mountains have obviousty been primary sources. The Pannonian deposits which were already in the Carpathian Basin during the glaciations must not be forgotten either. The deposits have provided plenty of material for fluvial and aeolian re-accumulation.

Zeuner's (1959 p. 93) statement that the weathering of soils in younger loesses is comparatively weakly developed also holds good with the loesslayers at Mende, the reason being the lowering in temperature of the climate. Würm III was the coldest period during the last glaciation (Šegota 1967 p. 132). The periods of interstadials became continously shorter.

Acknowledgements - My hearty thanks are due to Professor Mártón Pécsi, Ph.D., Hungarian Academy of Sciences, and the staff of his Department for their friendly guidance during my field-trips.

It would not have been possible to do the dating without Professor Birger Ohlson's very positive attitude and kindness and I am grateful to him for this.

Mr. Heikki Papunen, Phil. lic., Department of Geology at the University of Turku, kindly helped me to operate the Atomic Absorption Spectrophotometer during the calcium and magnesium analyses.

This investigation was aided financially by the FinnishHungarian Cultural Committee.

My thanks are also due to the Department of Geography at the University of Turku for the permission to use the laboratory and for covering the expenses of the equipment needed in the investigation. 


\section{REFERENCES}

Ādám, László; Marosi, Sándor \& Szilárd, Jenö (1954) A Paksi löszfeltárás. Zusammenfassung: Der Lössaufschluss von Paks. Földrajzi Közlemények 2, $239-254$.

BERG, L. S. (1964) Loess as a product of weathering and soil formation. (Translated from Russian). Israel Program for Scientific Translations. 207 p. Jerusalem.

BüDEL, Julrus (1960) Die Gliederung der Würmkaltzeit. Würzburger Geographische Arbeiten 8, 1-45.

Charlesworth, J. K. (1966) The Quaternary Era. Vol. 1. 591 p. London.

FINK, J. (1962) Studien zur absoluten und relativen Chronologie der fossilen Böden in Österreich. II. Wetzleinsdorf und Stillfried. Archaelogia Austriaca 31, $1-18$.

- (1964) Die Gliederung der Würmeiszeit in Österreich. Report of the VIth INQUA Congress Warsaw 1961. Vol. IV, 451-462.

Flint, Richard Foster (1967) Glacial and Pleistocene Geology. 553 p. New York.

Frenzel, Burkhard (1964) Zur Pollenanalyse von Lössen. Eiszeitalter und Gegenwart 15, 5-39.

Gross, Hugo (1962-63) Der gegenwärtige Stand der Geochronologie des Spätpleistozäns in Mittel- und Westeuropa. Quartär 14, 49-68.

Guenther, EkKE W. (1961) Sedimentpetrographische Untersuchung von Lössen. Zur Gliederung der Eiszeitalters und zur Einordnung paläolithischer Kulturen. Teil I. 77 p. Köln-Graz.

HaAse, Günter (1963) Stand und Probleme der Lössforschung in Europa. Geographische Berichte 27, $97-129$.

Ivanova, I. K. (1969) Les loess de la partie sud-ouest du territoire européen de l'U. R. S. S. et leur stratigraphie. La Stratigraphie des Loess d'Europe. Supplément au Bulletin de l'Association Francaise pour l'Étude du Quaternaire, 151-159.

KádÁr, LÁszLó (1960) Climatical and other conditions of loess formation. Studies in Hungarian Geographical Sciences (ed. Gyula Miklós), Budapest, 17-24.

KubiËNA, W. L. (1953) Bestimmungsbuch und Systematik der Böden Europas. 392 p. Stuttgart.

Kungl. LANTBRukSSTYRELSENS Kungörelser M. M. (1965) Nr 1, 1-20. Solna.

Kukla, J. \& Lozek, V. (1969) Trois profils caractéristiques de la Bohême Centrale et de la Moravie du Sud. La Stratigraphie des Loess d'Europe. Supplément au Bulletin de l'Association Francaise pour l'Étude du Quaternaire, 53-56.

Kuyl, O. S. \& Bisschops, J. H. (1969) Le loess aux Pays-Bas. La Stratigraphie des Loess d'Europe.
Supplément au Bulletin de l'Association Francaise pour l'Étude du Quaternaire, 101-104.

Köster, Erhard (1964) Granulometrische und morphometrische Messmethoden an Mineralkörnern, Steinen und sontigen Stoffen. 336 p. Stuttgart.

Lorch, WALter (1940) Die siedlungsgeographische Phosphatmethode. Die Naturwissenschaften 28, 633-640.

Munsell soil color charts. U. S. Dept. Agriculture Handbook 18. (1954) Baltimore.

PaEpe, Roland (1969) Les unités litho-stratigraphiques du Pléistocene supérieur de la Belgique. La Stratigraphie des Loess d'Europe. Supplément au Bulletin de l'Association Francaise pour l'Étude du Quaternaire, $45-51$.

PÉcsi, Márton (1964) Ten years of physico geographic research in Hungary. 132 p. Budapest.

- (1965 a) Der Lössaufschluss von Mende. Földrajzi Közlemények 13, 332-338.

- (1965 b) Zur Frage der Typen der Lösse und Lössartigen Sedimente im Karpatenbecken und ihrer lithostratigraphischen Einleitung. Földrajzi Közlemények 13, 305-323.

- (1966) Lösse und lössartige Sedimente im Karpatenbecken und ihre lithostratigraphische Gliederung I-II. Petermanns Geographischen Mitteilungen 110, $176-189,241-252$.

- (1968) Loess. The Encyclopedia of Geomorphology (ed. Rhodes W. Fairbridge), New York, 674-678.

- \& HaHn, G. (1969) Historique des recherches sur le loess en Hongrie. La Stratigraphie des Loessd'Europe. Supplement au Bulletin de l'Association Francaise pour l'Étude du Quaternaire, 85-91.

- \& Pécsiné, DonÁth Éva (1959) Elemzö módszerek alkalmazá a geomorfológiai kutatásban. Zusammenfassung: Die Anwendung analytischer Forschungsmethoden in der Geomorphologie. Földrajzi Értesitö $8,165-178$.

Radiocarbon 11 : 1 (1969) Published by The American Journal of Science. 244 p.

RóNAI, ANDRE (1965) Some observations concerning the Quaternary sedimentation in Hungary. Acta Geologica Hungarica 9, 17-32.

Ruhe, Robert V. (1968) Identification of paleosols in loess deposits in the United States. Loess and related eolian deposits of the world (ed. C. Bertrand Schultz and John C. Frey), Lincoln, Nebraska, 49-65.

ŠEgota, Tomislav (1967) Paleotemperature changes in the Upper and Middle Pleistocene. Eiszeitalter und Gegenwart 18, 127-141. 
Stefanovits, Pál (1965) Untersuchungsangaben der Begraben Bodenschichten im Lössprofil von Mende. Földrajzi Közlemények 13, 339-344.

Thun, Richard (1955) Die Untersuchung von Böden. Handbuch der landwirtschaftlichen Versuchs- und Untersuchungsmethodik (Methodenbuch) I. Dritte Auflage (ed. Erich Knickmann), 271 p. Berlin.
Woldstedt, Paul (1961) Das Eiszeitalter I. 374 p. Stuttgart.

Zeuner, Frederick E. (1959) The Pleistocene Period. Its Climate, Chronology and Faunal Successions. 447 p. London.

Manuscript received, May 25, 1970.

\section{APPENDIX}

\section{MINERAL ANALYSES OF THE LOESS SAMPLES}

by

Kalevi Punakivi and Matti Seppälä

The minerals in loess samples $1-15$ (p. 111) in the present paper were examined by means of $X$-ray diffraction, differential thermal and thermogravimetric analyses.

\section{INTERPRETATION OF $X$-RAY DIAGRAMS}

The apparatuses used were a Philips $X$-ray diffraction Generator PW-1010 and Goniometer PW-1050 of the Geological Survey of Finland.

$\mathrm{CuK} \alpha$ radiation and a $\mathrm{Ni}$ filter were used in the analyses. The Goniometer speed was $2^{\circ} \Theta / \mathrm{min}$, and slides were orientated.
Fresh loesses generally contained abundant calsite and dolomite. Illite, chlorite, quartz and plagioclase occurred in all the samples. Weathered loesses had more clay minerals than fresh loesses.

Sample 10 contained considerably more carbonates than the other samples. Sample 15 had no carbonates according to the analysis ( $c f$. Fig. 2 p. 111). It must be pointed out, however, that even as much as $5 \%$ calsite may remain undetected in $X$-ray analyses (Webb \& Heystek 1957 p. 329).

TABle 1

Occurrence intensities of minerals estimated on the basis of the $X$-ray diffractions

\begin{tabular}{|c|c|c|c|c|c|c|c|c|c|}
\hline \multirow[t]{2}{*}{ No } & Chlorite & Illite & Chlorite & Quartz & $\begin{array}{c}\text { Quartz } \\
\text { and Illite }\end{array}$ & Orthoclase & Plagioclase & Calsite & Dolomite \\
\hline & $14.0 \AA$ & $10.0 \AA$ & $7.1 \AA$ & $4.26 \AA$ & $3.33 \AA$ & $3.24 \AA$ & $3.20 \AA$ & $3.04 \AA$ & $2.89 \AA$ \\
\hline $1 \ldots \ldots$ & - & w & $\mathrm{w}$ & $\mathrm{m}$ & vs & vw & $\mathrm{vw}$ & $\mathrm{s}$ & $\mathrm{m}$ \\
\hline $2 \ldots \ldots \ldots$ & vw & vw & - & $\mathrm{vw}$ & vs & - & w & w & vw \\
\hline $3 \ldots \ldots$ & - & vw & $\mathrm{vw}$ & $\mathrm{w}$ & vs & - & $\mathrm{w}$ & $\mathrm{s}$ & $\mathrm{m}$ \\
\hline $4 \ldots \ldots \ldots$ & vw & $\mathrm{w}$ & $\mathrm{w}$ & $\mathrm{m}$ & vs & - & $\mathrm{m}$ & w & $\mathrm{m}$ \\
\hline $5 \ldots \ldots \ldots$ & - & w & w & $\mathrm{m}$ & s & - & w & $\mathrm{m}$ & s \\
\hline $6 \ldots \ldots \ldots$ & w & $\mathrm{m}$ & $\mathrm{m}$ & $\mathrm{m}$ & vs & $\mathrm{vw}$ & $\mathrm{m}$ & s & s \\
\hline $7 \ldots \ldots \ldots$ & w & s & $\mathrm{m}$ & $\mathrm{w}$ & s & $\mathrm{vW}$ & $\mathrm{v}$ & $\mathrm{v}$ & - \\
\hline $7 C \ldots \ldots$ & - & w & $\mathrm{vw}$ & $\mathrm{m}$ & vs & $\mathrm{vw}$ & $\mathrm{m}$ & vw & vw \\
\hline $8 \ldots \ldots \ldots$ & vw & w & $\mathrm{w}$ & $\mathrm{w}$ & s & $\mathrm{vW}$ & w & $\mathrm{m}$ & vw \\
\hline $9 \ldots \ldots \ldots$ & vw & $w$ & $\mathrm{~m}$ & $\mathrm{~m}$ & vs & $\mathrm{m}$ & w & $\mathrm{m}$ & - \\
\hline $10 \ldots \ldots \ldots$ & - & $\mathrm{m}$ & w & $\mathrm{m}$ & s & $\mathrm{vw}$ & w & $\mathrm{s}$ & s \\
\hline $11 \ldots \ldots$ & vw & vw & $\mathrm{w}$ & $\mathrm{w}$ & $\mathrm{m}$ & - & vw & $\mathrm{m}$ & $\mathrm{w}$ \\
\hline $12 \ldots \ldots \ldots$ & vw & w & w & $\mathrm{m}$ & vs & $\mathrm{vw}$ & w & s & $\mathrm{m}$ \\
\hline $13 \ldots \ldots \ldots$ & - & w & w & vs & 一 & $\mathrm{m}$ & $\mathrm{m}$ & $\mathrm{m}$ & $\mathrm{m}$ \\
\hline $14 \ldots \ldots \ldots$ & - & $\mathrm{vw}$ & $\mathrm{vw}$ & s & vs & vw & $w$ & vw & $\mathrm{vw}$ \\
\hline $15 \ldots \ldots$ & - & $\mathrm{vw}$ & $\mathrm{vw}$ & $\mathrm{m}$ & $\mathrm{s}$ & vw & vw & - & 一 \\
\hline
\end{tabular}

$\mathrm{vs}=$ very strong, $\mathrm{s}=$ strong, $\mathrm{m}=$ medium, $\mathrm{w}=$ weak, $\mathrm{vw}=$ very weak. 


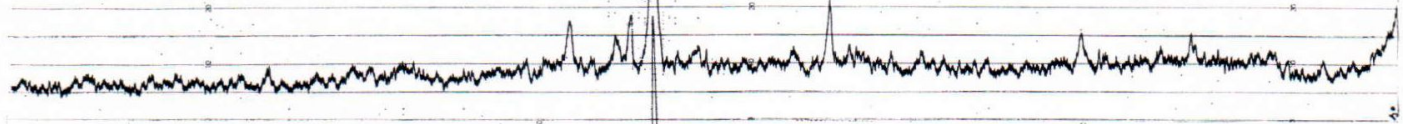
1

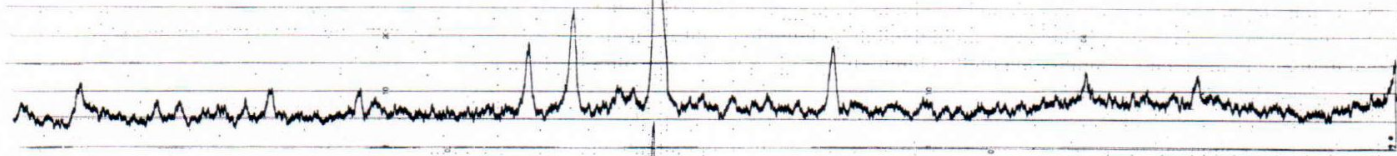
10

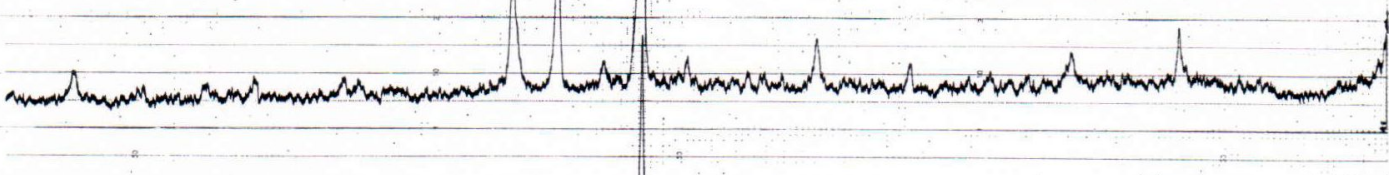

6

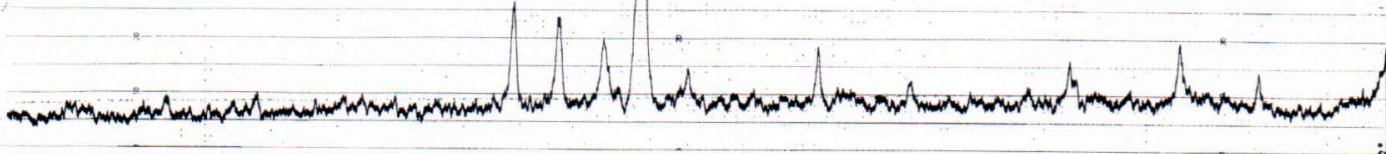

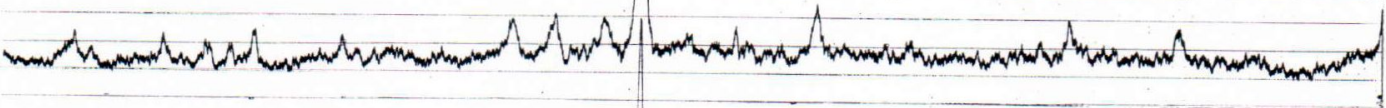
12

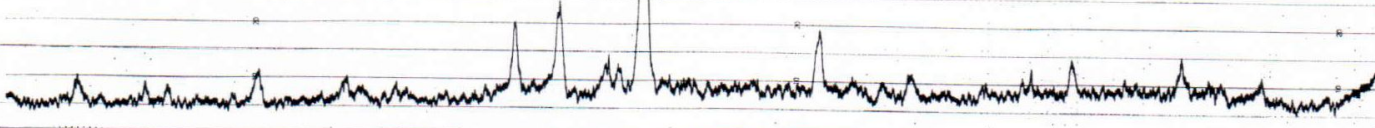

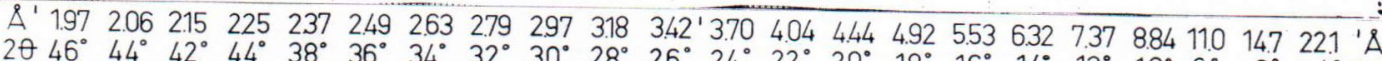
$2 \theta 46^{\circ} 44^{\circ} 42^{\circ} 44^{\circ} 38^{\circ} 36^{\circ} 34^{\circ} 32^{\circ} 30^{\circ} 28^{\circ} 26^{\circ} 24^{\circ} 22^{\circ} 20^{\circ} 18^{\circ} 16^{\circ} 14^{\circ} 12^{\circ} 10^{\circ} 8^{\circ} 6^{\circ} 4^{\circ} 2 \theta$

Fig. 1. $X$-ray diagrams of some loess samples from Mende. For numbers of the samples, see page 111. 


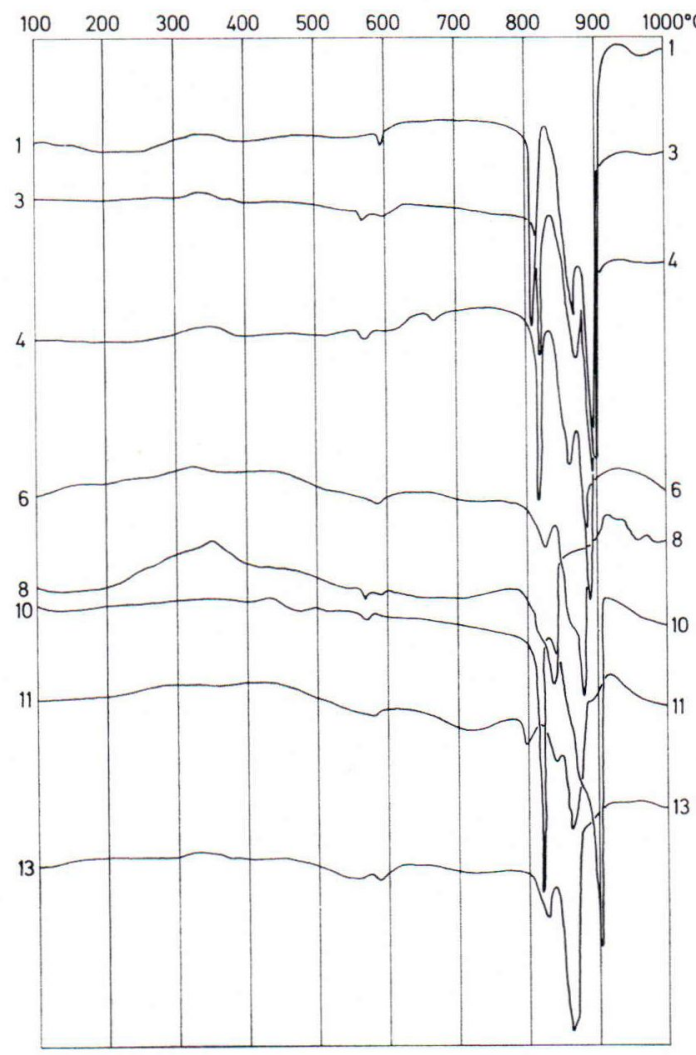

Fig. 2. Differential thermal curves of the samples of fresh loesses.

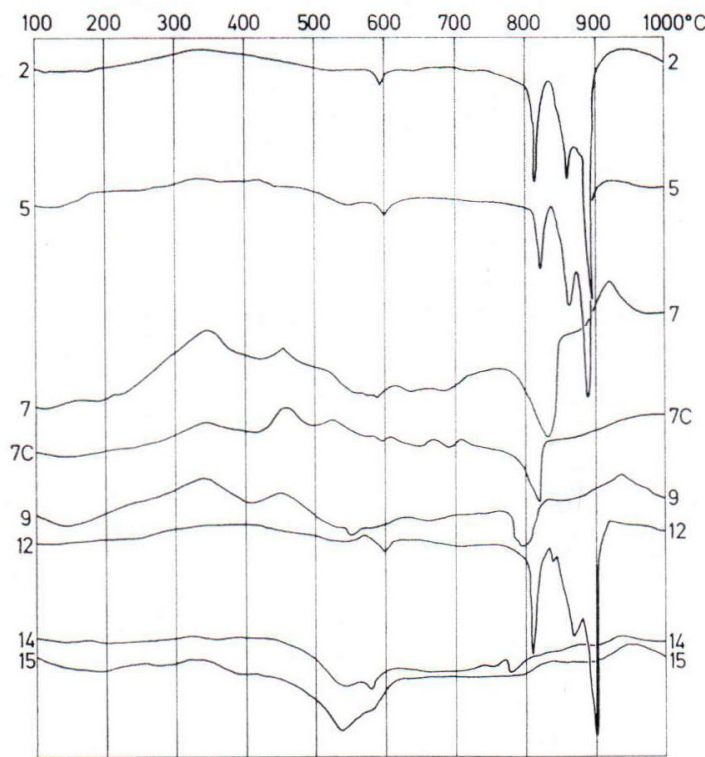

Fig. 3. Differential thermal curves of weathered loess layers.

\section{INTERPRETATION OF DIFFERENTIAL THERMAL CURVES}

In DTA, the measuring units were a Leeds \& Northrup $\mathrm{X}-\mathrm{Y}$-recorder and temperature-regulating system, a specimen holder constructed by Geological Survey of Finland and furnaces made by Oy E. Sarlin Ab.

The samples analysed in DTA were 0.8 grams of ground raw material. The increase of temperature was $10^{\circ} \mathrm{C} / \mathrm{min}$ in air atmosphere.

Differential thermal methods are very suitable for analysing carbonates. Small amounts such as 0.3 per cent dolomite (Rowland \& Beck 1952) and 1 per cent calsite (Kulp, Kent \& Kerr 1951) can be detected.

Endothermic decomposition is the most characteristic feature of carbonates (Webb \& Heystek 1957 p. 330). Wide particle-size range causes broad endothermic peaks (Kulp, Kent \& Kerr 1951). Peak temperatures vary depending on the calcium carbonate content. The temperatures of undiluted calcite vary from $860^{\circ} \mathrm{C}$ to $1010^{\circ} \mathrm{C}$,

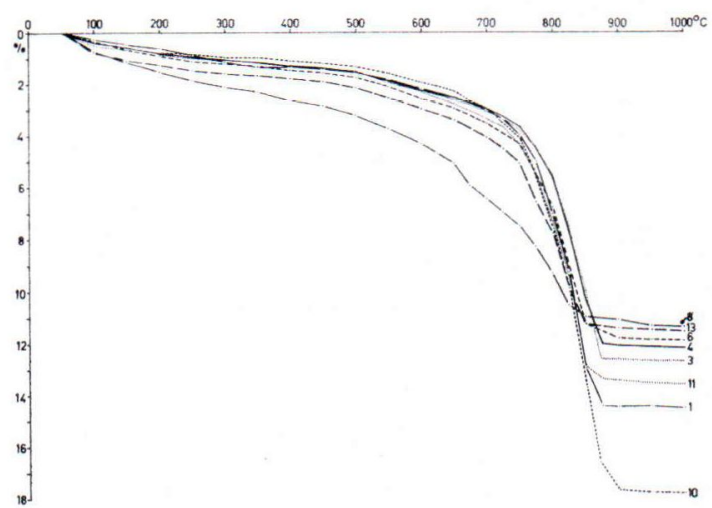

Fig. 4. Thermogravimetric curves of fresh loesses.

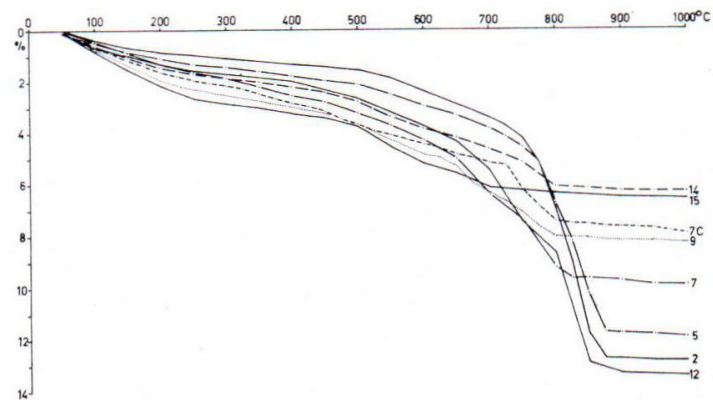

Fig. 5. Thermogravimetric curves of weathered loesses. 


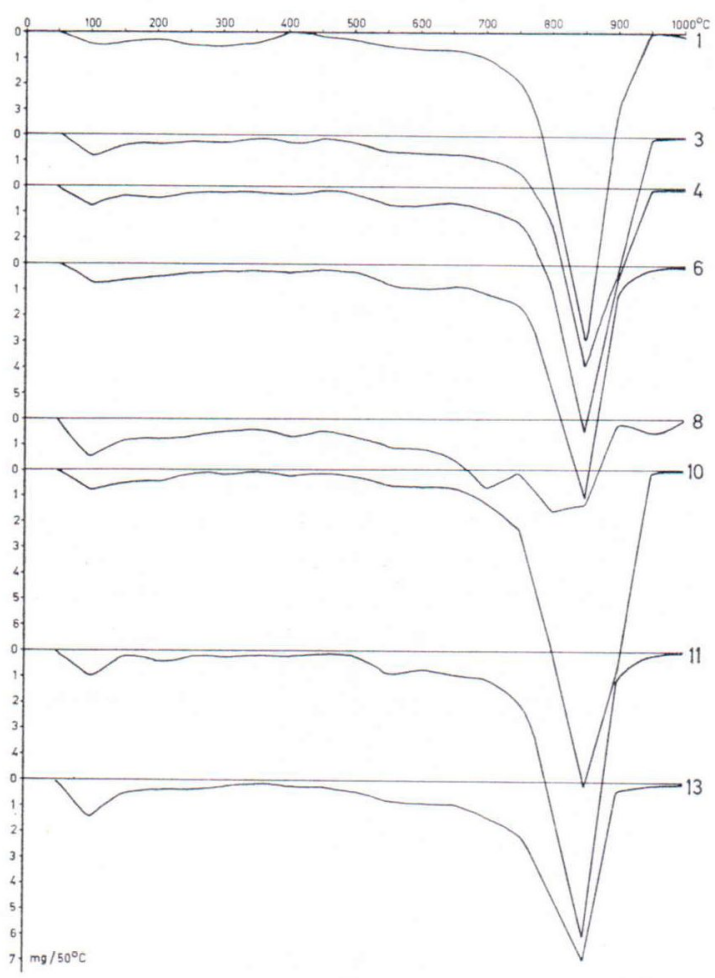

Fig. 6. Differential thermogravimetric curves of fresh loesses.

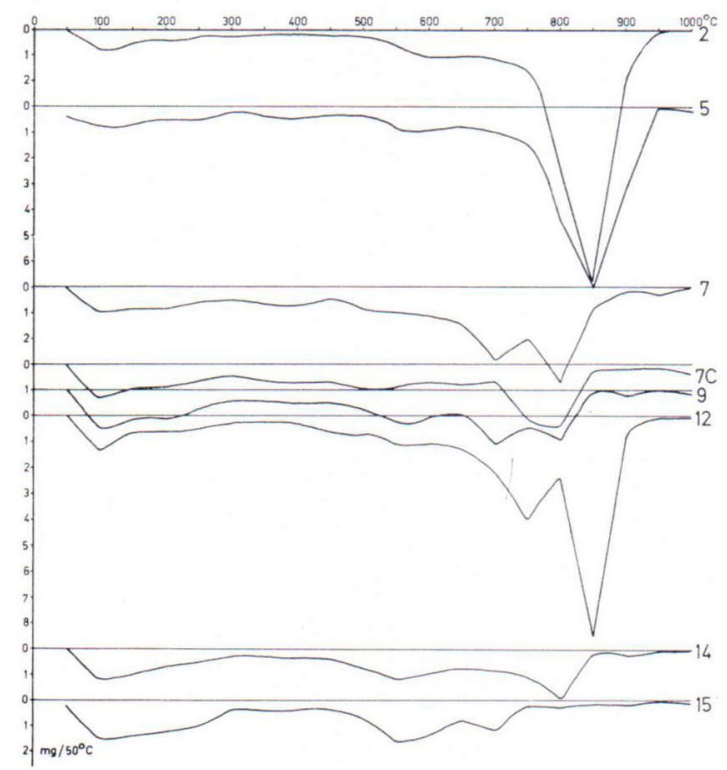

Fig. 7. Differential thermogravimetric curves of weathered loesses. and those of $20-25$ per cent calsite from $830^{\circ} \mathrm{C}$ to $940^{\circ} \mathrm{C}$ (Webb \& Heystek 1957 p. 331).

Dolomite has two characteristic peaks whose temperatures are between $790^{\circ} \mathrm{C}$ and $940^{\circ} \mathrm{C}$ (Webb \& Heystek 1957 p. 338).

Soluble salts are found to be a major cause of the variations in the position and shape of the lower-temperature endothermic deflection in the DTA curves of a member of low-iron sedimentary dolomites (Graf 1952).

The triple peaks which fell between $800^{\circ} \mathrm{C}$ and $900^{\circ} \mathrm{C}$ in the analyses show that the samples contain both calsite and dolomite (e.g. samples 1-4, Figs. 2 and 3). The second peak in sample 10 appears only as a slightly arched bend in the curve.

The first peak falls between $780^{\circ} \mathrm{C}$ and $840^{\circ} \mathrm{C}$ in the analyses. Samples whose DTA curves have only the first peak contain mostly only calsite (samples 7-9). The midmost peak falls between $840^{\circ} \mathrm{C}$ and $870^{\circ} \mathrm{C}$ and the third peak between $865^{\circ} \mathrm{C}$ and $905^{\circ} \mathrm{C}$.

The last peak in samples 1,6 and 10 is bigger than the others, which seems to mean that they contain plenty of dolomite.

The exothermic peak between 300 and $400^{\circ} \mathrm{C}$ is probably due to the burning of humus (Soveri 1951 p. 31).

The endothermic peak between 450 and $650^{\circ} \mathrm{C}$ is caused mostly by illite and to some extent by chlorite (Soveri 1951 p. 35-43). This analysis also proves that soil horizons have considerably more clay minerals than fresh loesses.

\section{INTERPRETATION OF THERMOGRAVIMETRI- CAL ANALYSES}

A Stanton Thermobalance HT-D was used in the TG analyses. The increase of temperature in the thermobalance was $6.6^{\circ} \mathrm{C} / \mathrm{min}$ and the analysed amounts of material $200 \mathrm{mg}$.

The TG-curves show that the weight of fresh loesses decreases more on the average than that of the samples from soil horizons when they were heated to $1000^{\circ} \mathrm{C}$. This is directly proportional to the amount of carbonates.

The weight of weathered loesses decreases more evenly than that of fresh ones (samples 9, 14 and 15). Samples 2, 5 and 12 are much less weathered than the others, which is also shown clearly by the DTG diagrams (Fig. 7). Sample 8 has clear signs of weathering (Fig. 6).

\section{CONCLUSIONS}

The analyses showed that the mineral composition of loesses depends a great deal on their stage of weathering. As the soiling process continued the amount of carbonates decreased and that of clay minerals generally increased, 
even though clay and primary minerals occurred in all the layers.

The results of the $X$-ray analysis must be considered to be mainly qualitative. The amounts of calsite in particular cannot be detected clearly enough.
When comparing the total amounts of calcium and magnesium obtained by means of chemical analyses (Fig. 2 p. $\mathrm{xxx}$ ) with the weight losses observed in the TG analyses, a high correlation is noticed between them $(r=0.97)$.

\section{REFERENCES}

Graf, Donald F. (1952) Preliminary report on the variations in differential thermal curves of low-iron dolomites. The American Mineralogist 37, 1-27.

Kulp, J. Laurence, Kent, Purfield \& Kerr, Paul F. (1951) Thermal study of the $\mathrm{Ca}-\mathrm{Mg}-\mathrm{Fe}$ carbonate minerals. The American Mineralogist 36, 643-670.

Rowland, Richard A. \& Beck, Carl W. (1952) Determination of small quantities of dolomite by differential thermal analysis. The American Mineralogist $37,76-82$.

SOveri, U. (1951) Differential thermal analyses of some Quaternary clays of Fennoscandia. Annales Academiae Scientiarum Fennicae Ser. A III: 23, 1-103.

Webi, T. L. \& Heystek, H. (1957) The carbonate minerals. The differential thermal investigation 0 , clays (ed. Robert C. Mackenzie), London, 329-363. 